CURRENT BIOCHEMISTRY

ISSN: 2355-7877

Homepage: http://biokimia.ipb.ac.id

E-mail: current.biochemistry@gmail.com

\title{
The Usage of Momordica charantia as Face Cleansing Cosmetics: Momordica charantia Leaves Extract as Absorbent of Heavy Metal, Surface Tension Reducer and Skin Antibacterial
}

\author{
Dimas Andrianto ${ }^{1 *}$, Popi Asri Kurniatin ${ }^{1}$, Silvy Aulya ${ }^{1}$, Dewi Eriyanti ${ }^{1}$ \\ ${ }^{1}$ Department of Biochemistry, Bogor Agricultural University, Bogor, 16680, Indonesia
}

Corresponding author: Dimas Andrianto; Departemen Biokimia, Jl. Agatis Gd. Fapet Lt. 5, Wing 5, Bogor 16680; Telp/ Fax.+62251-8423267; Email: dimasandriantoo@gmail.com

\begin{abstract}
Momordica charantia (daun pare in Indonesian) is one of Indonesian herbal plants which useful property has not been explored. $M$. charantia contains chemical substances such as oil and saponin. Nowadays, the society possesses a high awareness regarding the risk of using artificial chemicals for skin care and more people are switching to use herbal cosmetics. The extract of $M$. charantia has been proven to be able to be used as one of the active components of herbal based facial cleansing cosmetics. Its active properties include its ability to absorb heavy metal from air pollution and motor vehicles emission, decrease surface tension, and to act as an antibacterial agent.In the research, $M$. charantia was extracted using 4 (four) solvents, namely water, ethanol, methanol, and hexane. The research then examined the property of each extract in metal absorption (using Atomic Absorption Spectrophotometry / AAS), decreasing surface tension, and antibacterial activities. The result of the test showed that the water based extract was the most effective extract in reducing surface tension and in inhibiting the development of Escherichia coli and Staphylococcus aureus bacteria, while the ethanol based extract was the most effective one in absorption of $\mathrm{Pb}$ and $\mathrm{Hg}$ metals and in inhibiting the development of Staphylococcus epidermidis bacteria. The result indicated that M. charantia extract has the potentials to be used as facial cleanser and can also counter the bacterial infection which could cause acnes.
\end{abstract}

Keywords: Momordica charantia, cosmetics, surface tension, metal absorbent, antibacterial 


\section{INTRODUCTION}

Cosmetics are one of the most important elements in women's appearance. Cosmetics are widely varied in types and brands. In 2010, there were 112545 items of cosmetics were available in Indonesia's market with the trade value of $\mathrm{Rp}$. 8.9 trillion (Perkosmi 2011 in Kusdriana 2011). One of the types of cosmetics is facial cleanser. The increasing level of pollution, dust, and cigarette smoke rendered facial cleanser one of the main necessities of every individual. Cleansing one's face from dirt, oil, and other residues using soap should be done regularly. It is advised to use type of soap which is compatible with skin type, especially to clean the face (Andrianto 2012).

There were only 10926 items out of 112545 cosmetic products which had been notified on line in May 2011 (BPOM 2011 in Kusdriana 2011). This condition worried the society since, nowadays, there are cosmetic products available in the market which contain dangerous chemicals for facial health such as mercury, hydroquinone, retinoic acid, and dangerous coloring agents. In fact, some of those cosmetic products were recalled from the market due to using their dangerous chemical ingredients (Kompas 2009).

Therefore, a herbal cosmetic product based on authentic Indonesian natural resources should be developed. $M$. charantia has useful properties to be used in medicine for worm infection, cough, regular period for women, constipation, syphilis, liver problem, also to increase appetite and breast milk production (Kuswoyo 2009). M. charantia is usually used as medicinal plant. Its chemical substances which have the potentials to be used for facial cleanser are oil and saponin from its leaves extract.

Oil and saponin from $M$. charantia leaves extract would cleanse the skin from pollutants such as dust, dirt, and make up residues. The cleansing works similarly of that the active coal bonding in modern facial cleanser (Meilita \&Tuti 2010).

The research involved metal absorption test using AAS, surface tension test, and antibacterial test in order to examine the potentials of M.charantia as facial cleanser's active ingredient: metal absorption test was conducted to examine the ability of M.charantia extract in absorbing heavy metals from air pollution (Suardana 2008); surface tension test was conducted to examine the extract's ability in diluting pollutants by reducing surface tension; and antibacterial test was conducted to examine the property of the extract in inhibiting the growth of common bacteria which cause infection, which include Escherichia coli, Staphylococcus aureus, and Staphylococcus epidermidis.

The research was inspired by the traditional knowledge and customs of the people in the city of Wonosobo , Central Java Province and Padang Pariaman, West Sumatra Province, which have been using M.charantia for generations as facial cleanser. Normally, M.charantia leaves are squeezed in a clean water, and then applied to the face.

The objective of the research is to examine M.charantia leaves extract as an active ingredient in facial cleanser cosmetics. The objective is obtained through 3 phases of research, namely: heavy metal absorption test; surface tension test; and antibacterial activities test. Heavy absorption test is conducted to examine the capacity of the extract to absorb pollutants in the forms of heavy metals, including lead $(\mathrm{Pb})$ 
and mercury $(\mathrm{Hg})$. Surface tension test is to be conducted to examine the extract's ability in diluting pollutants by reducing surface tension. Antibacterial test is conducted to examine the property of the extract in inhibiting the growth of common bacteria which cause infection, which include Escherichia coli, Staphylococcus aureus, and Staphylococcus epidermidis.

The scientific benefit of the research is determining whether M.charantia leaves extract could act as a safe and effective active ingredient in Indonesian herbal based facial cleanser. On the other hand, the commercial benefit of the research is the potential availability of safe and beneficial cosmetics with M.charantia leaves extract as active ingredient.

\section{METHODOLOGY}

The $M$. charantia leaves used in the research were obtained from plantation in the village of Cibeureum, Municipality of Bogor. The extraction and antibacterial test are conducted in the laboratory of Biochemistry Department, Bogor Agricultural University. The surface tension test is conducted in the laboratory of Physics Department, Bogor Agricultural University. The metal absorption test is conducted in the Center of Biopharmaceutical Studies, Bogor Agricultural University. The research was conducted from October 2011 to May 2012.

\section{Materials and Equipment}

The materials used in the research comprised M. charantia leaves, aquadest, ethanol, methanol, n-hexane, phytochemical test reactor, 5,000 ppm mercury $(\mathrm{Hg})$ and lead $(\mathrm{Pb})$ solutions, liquid nutrient media, jelly nutrient media, and bacterial isolates for Escherichia coli,Staphylococcus aureus, and Staphylococcus epidermidis.
Equipment employed in the research comprised oven, rotary evaporator, Atomic Absorption Spectrophotometer (AAS), surface tension measurement device, Petri dish, laminar air flow cabinet, and other glass equipment.

\section{Method}

M.charantia leaves extraction (BPOM 2004). M.charantia leaves were cleaned and dried in the oven until the water content reached less than $10 \%$. The dried leaves were then pounded to the size of 80 mesh. The powder from the leaves was then macerated in solution of water, ethanol, methanol, and n-hexane with 1:10 ratio for 24 hours. Afterwards, the macerates were filtered and the filtrates were separated; the sedimentswere extracted again 3 times. Acquired filtrates were gathered and thickened using rotary evaporator.

\section{Phytochemical screening (Harborne 1998).}

The tests conducted comprised phenolic test, flavonoid test, alkaloid test, tannin test, saponin test, triterpenoid test, steroid test, and glycoside test.

Metal Absorption Test (Andrianto et al. 2012). Tested metal in the research consisted of $\mathrm{Hg}$ and $\mathrm{Pb}$ using AAS. Active charcoal was used as positive control. The stock of $\mathrm{Hg}$ and $\mathrm{Pb}$ solutions were prepared with 5,000 ppm concentration in a $25 \mathrm{ml}$ volumetric flask. The extracts of water, ethanol, methanol, n-hexane and active charcoal, each 0.25 grams, were added to each $\mathrm{Hg}$ and $\mathrm{Pb}$ stock. The solution was then left for 15 minutes then filtered. The filtrate was then dilutedfor 100 times dilution. The metal absorption was measured using AAS. 
Surface tension test. The extract was prepared in 10 times 0.1 grams samples and then each of them was diluted in $100 \mathrm{ml}$ of aquadest. The first sample, with $0.1 \%$ concentration, was measured using surface tension measurement device. The solution was then thickened by adding the second sample to it (another 0.1 grams), thus having $0.2 \%$ concentration, and its surface tensioned measured again. This practice was continued until the concentration of the solution reaches $1 \%$.

Antibacterial test. Tested bacteria included Escherichia coli, Staphylococcus aureus, and Staphylococcus epidermidis. As $100 \mu \mathrm{L}$ of sterile media were prepared; $40 \mu \mathrm{L}$ of the sample was diluted in $20 \%$ DMSO; $10 \mu \mathrm{L}$ of bacterial inoculums was separated and then inserted to a 96-well plate; this practice was conducted four times so that four samples were acquired. The inoculum was prepared in $10^{-2} \mathrm{CFU} / \mathrm{ml}$ concentration. The tested bacteria were incubated in the media for 48 hours in $37^{\circ} \mathrm{C}$ temperature. The concentration of the extract which visually did not show bacterial development (clear) was described as Minimum Inhibitory Concentration (MIC). As $100 \mu \mathrm{L}$ of media which did not show bacterial development was inoculated to $100 \mu \mathrm{L}$ of new media, then incubated for 48 hours in $37^{\circ} \mathrm{C}$ temperature. The concentration of the extract which did not show bacterial development after second inoculation was described as Minimum Bactericidal Concentration (MBC). The negative control used was DMSO and positive control used consisted of tetracycline and erythromycin.

Data analysis. Surface tension was calculated based on the following formula:

$$
\gamma=\frac{F}{2 L}
$$

with $\gamma$ represents surface tension $(\mathrm{N} / \mathrm{m})$, F represents force (Newton), and $\mathrm{L}$ represents the length of fluid layer's surface (m). Other data were analyzed based on their average value and standard of deviation.

\section{RESULT AND DISCUSSION}

Phytochemical screening was conducted to observe the correlation of the extract's phytochemical substance with metal absorption, decrease of surface tension, and antibacterial activities. The result of the test showed that the water based, ethanol based, methanol based, and n-hexane based extracts of M.charantia contained flavonoid, alkaloid, triterpenoid, and glycoside (Table 1). Meanwhile, saponin was found in water based and ethanol based extracts, and steroid was found in methanol based and n-hexane based extracts.

Table 1. Phytochemical test of M.charantia extracts

\begin{tabular}{|c|c|c|c|c|}
\hline \multirow{2}{*}{ Test } & \multicolumn{5}{|c|}{ Extract } \\
\cline { 2 - 5 } & Water & Ethanol & Methanol & n-Hexane \\
\hline Phenolic & - & - & - & - \\
\hline Flavonoid & + & + & + & + \\
\hline Alkaloid & + & + & + & + \\
\hline Tannin & - & - & - & - \\
\hline Saponin & + & + & - & - \\
\hline $\begin{array}{c}\text { Triter- } \\
\text { penoid }\end{array}$ & + & + & + & + \\
\hline Steroid & - & - & + & + \\
\hline Glycoside & + & + & + & + \\
\hline
\end{tabular}


The result of the test showed that all types of M.charantia extract could absorb mercurial metal (Hg) (Figure 1). Active charcoal absorption was measured as the positive control. Active charcoal with $1 \%$ concentration could absorb $27.4 \% \mathrm{Hg}$ metal, $1 \%$ of water based extract could absorb 5.8\% metal, ethanol based extract absorbed 30.2\% metal, methanol based extract absorbed 10.2\% metal, and n-hexane based extract absorbed $26.9 \%$ metal. This result showed that M.charantia's ethanol based extract was the most effective one in absorbing $\mathrm{Hg}$ metal.
Active charcoal as positive control in $1 \%$ concentration could absorb up to $41.5 \%$ lead metal $(\mathrm{Pb}), 1 \%$ of $M$. charantia's water based extract absorbed $37 \%$ of metal, ethanol based extract absorbed $48.2 \%$ of metal, methanol based extract absorbed $38.9 \%$ of metal, and n-hexane based extract absorbed $26.2 \%$ of metal (Figure 2). The result showed that the ethanol based extract was the most effective one to absorb $\mathrm{Pb}$ metal.

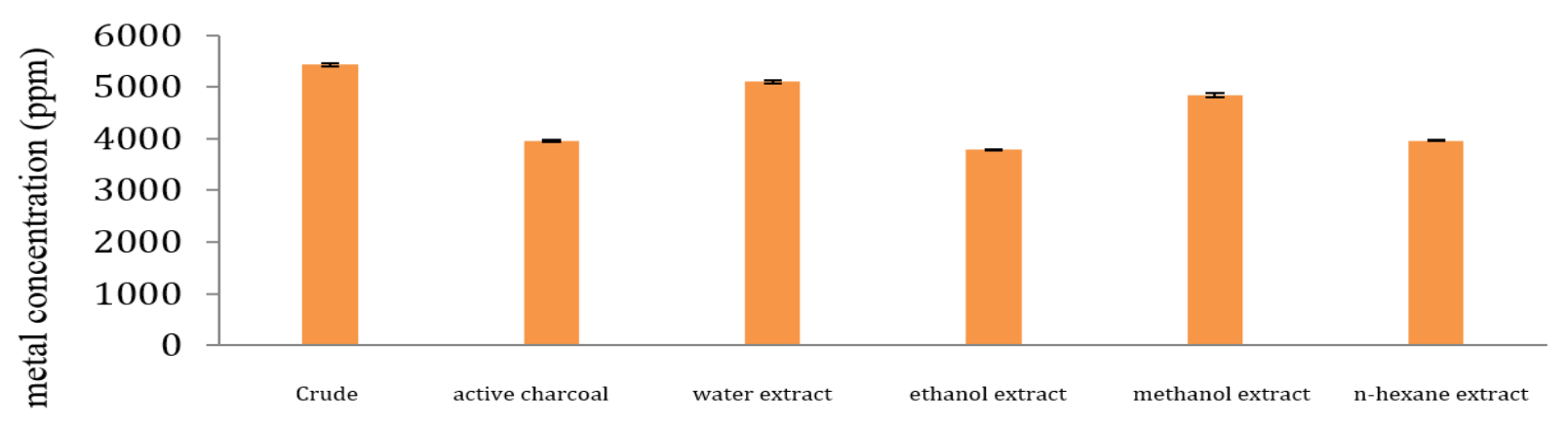

Figure 1. Mercurial (Hg) Metal Absorption of the Extracts

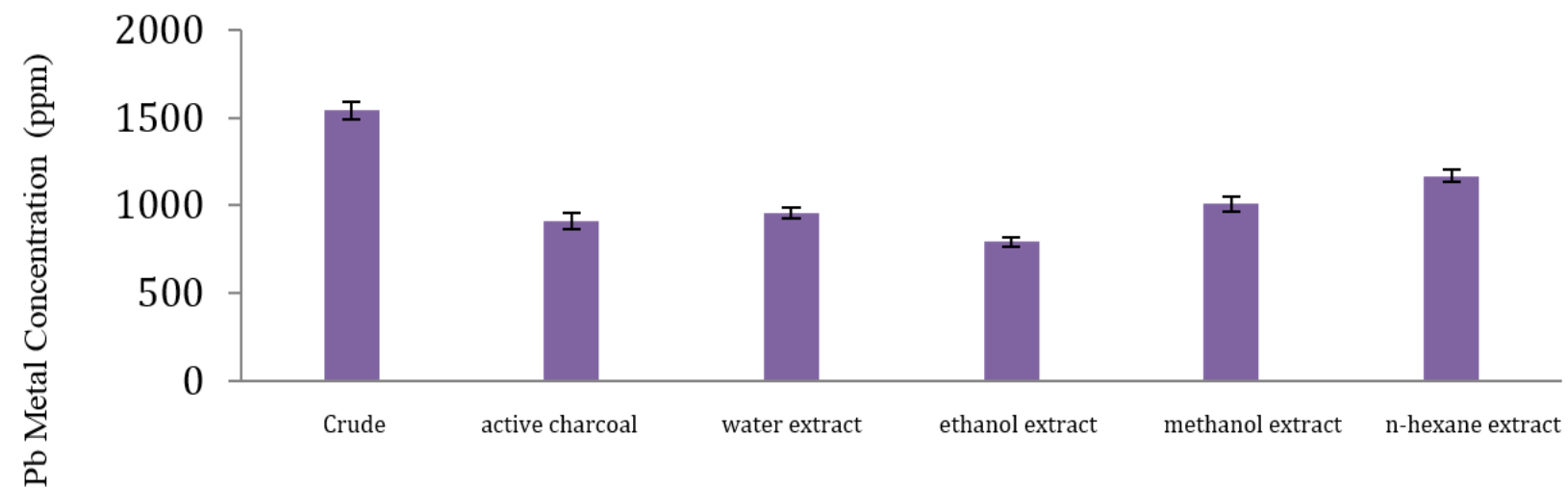

Figure 2. Lead $(\mathrm{Pb})$ Metal Absorption of the Extracts 
Surface tension test was conducted to examine the potential of M.charantia extract to assist decreasing surface tension so that it enlarged the liquid's surface (Nurzainah 2006). In daily life, surface tension reducer is used to clean dirt in clothes, because the decrease of surface tension would allow water/fluid/extract to penetrate deeper into the clothes and clean the dirt better. Surface tension was reduced by water and ethanol based extract of M.charantia (Figure 3), whereas methanol based extract of M.charantia could not reduce surface tension. $\mathrm{N}$-hexane based extract was not tested since the extract could not be dissolved, thus the surface tension measurement was unable to be performed using the extract.

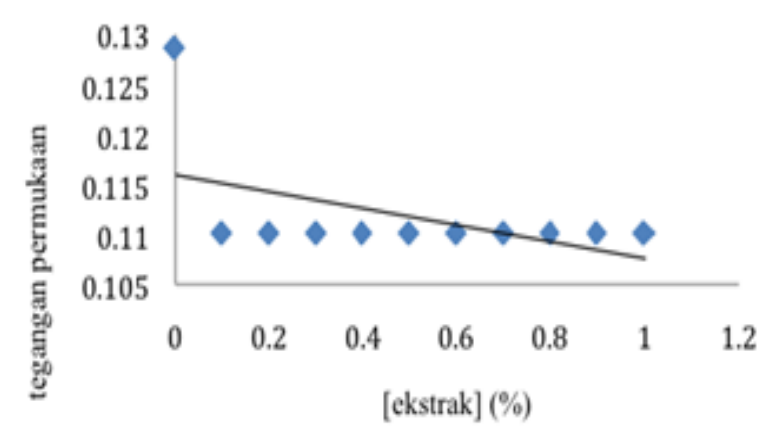

(a)

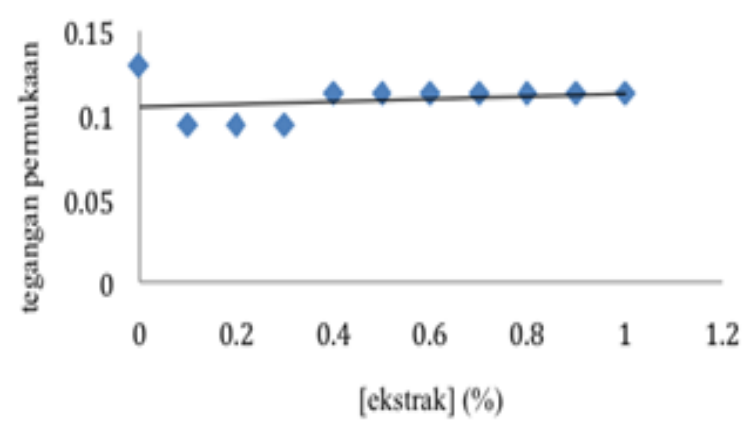

(b)

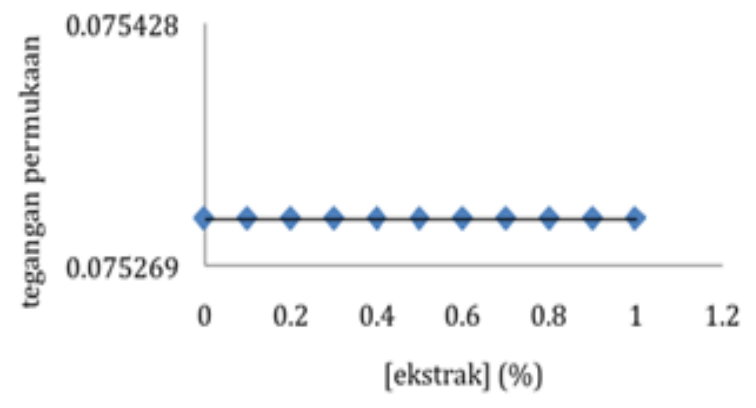

(c)

Figure 3: Surface tension reduction by (a) water, (b) ethanol, dan (c) methanol based extracts of M.charantia

The result of test showed that the water based extract of M.charantia in $0.1 \%$ concentration was able to reduce surface tension and the result was stable/consistent up to $1 \%$ concentration. Figure 3 showed that the water based extract of M.charantia was more effective in reducing surface tension compared to other extracts so that it possessed the highest potential to be used as active ingredient in facial cleanser.

Antibacterial test was conducted to examine the capability of $M$. charantia extracts, as one of the potential active ingredients in facial cleanser, in inhibiting bacterial growth. Table 2 showed that the water based extract of M. charantia could inhibit the growth of Escherichia coli in $250 \mathrm{ppm}$ concentration, while ethanol, methanol, and n-hexane showed similar activities in $1000 \mathrm{ppm}$ concentration. All extracts,with the exception of methanol based extract, could kill Escherichia coli bacteria in 2000 ppm concentration. The growth of Staphylococcus aureus bacteria could be inhibited in 2000 ppm concentration of all tested extract. Nevertheless, all the tested extracts up to the concentration of 2000 ppm could inhibit Staphylococcus aureus bacteria. Methanol and water 
Table 2. Antibacterial activities of different types of $M$. charantia extracts

\begin{tabular}{|c|c|c|c|c|c|c|c|c|}
\hline \multirow{2}{*}{ Bacteria } & \multicolumn{4}{|c|}{$\begin{array}{c}\text { Minimum Inhibitory Concentration } \\
\text { (ppm) }\end{array}$} & \multicolumn{4}{c|}{$\begin{array}{c}\text { Minimum Bactericidal Concentration } \\
\text { (ppm) }\end{array}$} \\
\cline { 2 - 10 } & Water & Ethanol & Methanol & Hexane & Water & Ethanol & Methanol & Hexane \\
\hline E. coli & 250 & 1000 & 1000 & 1000 & 2000 & 2000 & - & 2000 \\
\hline S. aureus & 2000 & 2000 & 2000 & 2000 & - & - & - & - \\
\hline S. epidermidis & 62.5 & 62.5 & 250 & 250 & - & 2000 & 2000 & - \\
\hline
\end{tabular}

based extracts were the most effective ones in inhibiting the growth of Staphylococcus epidermidis bacteria; in $62.6 \mathrm{ppm}$ concentration, the extract could already successfully inhibit the growth of the bacteria. Even so, only ethanol and methanol based extracts could successfully inhibit Staphylococcus epidermidis bacteria in 2000 ppm concentration.

Based on the result of the test conducted on M. charantia extracts using four different diluters, it was concluded that: water based extract of $M$. charantia has the most effectiveness in reducing surface tension and in inhibiting the growth of E.coli bacteria; ethanol based extract of $M$. charantia has the most effectiveness in absorbing $\mathrm{Pb}$ and $\mathrm{Hg}$ metals; and ethanol based extract of $M$. charantia has the most effectiveness in inhibiting the growth of $S$. epidermidis bacteria; while all extracts has the potentials in inhibiting the growth of $S$. aureus bacteria.

\section{REFERENCES}

Andrianto D, Anaser N, Untoro M, Fatmawati R, Winda RA, Aisyah S. 2012. Effect of Physallis peruviana L. leaves extract on the solubility of kidney stone in vitro. Prosiding Seminar Nasional Kimia.262-266.
Andrianto D, Pinilih P. 2012. Pengaruh tepung lidah buaya (aloe vera Linn.) terhadap aktivitas enzim tirosinase. [unpublished data]. Institut Pertanian Bogor: Departemen Biokimia.

[BPOM RI] Badan Pengawas Obat dan Makanan Republik Indonesia.2004. Ekstrak Tumbuhan Indonesia Vol. 2. Jakarta: BPOM.

Harborne JB. 1998. Phytochemical Methods. London: Chapman and Hall.

Kompas. 2009. BPOM Tarik 70 Produk Kosmetik Berbahaya. [online resource]. http://kesehatan.kompas.com/ $\mathrm{read} / 2009 / 06 / 11 / 12274413 / \mathrm{BPOM}$.Tarik.70.Produk.Kosmetik.Berbahaya

Kusdriana D. 2011.Daftar Peraturan Kosmetika di Indonesia. [online resource]. http:www.mediadata.co.id

Kuswoyo NP. 2009. Formulasi tablet hisap ekstrak daun pare (M. charantia L) secara granulasi basah dengan variasi konsentrasi PVP sebagai bahan pengikat [thesis]. Surakarta: Fakultas Farmasi, Universitas Muhammadiyah Surakarta.

Meilita TS danTuti SS. 2010.Arang Aktif (Pengenalan dan Proses Pembuatannya). [scientific paper]. Sumatera Utara :FakultasTeknik, Universitas Sumatera Utara.

Nurzainah Ginting. 2006. Penambahan Bahan Pengikat pada Nugget Itik Serati. Jurnal Agribisnis Peternakan 20 (1) : 6-10.

Suardana.2008. Optimalisasi Daya Adsorpsi Zeoli tterhadap Ion Kromium (III). JPPSH, Lembaga Penelitian Undiksha 2(1):1733. 